\title{
The Importance of Pheasant Population for Hunting Tourism in Vojvodina
}

\section{Zoran Ristić}

\begin{abstract}
Pheasant still remains, and will continue to be one of the most important kinds of game in Vojvodina's hunting-tourism. To achieve the desired results we need to increase the number of pheasant chicks than the current number. To do this we need to go back to the end of 70's and beginning of the 80 's. In this period, until the start of the 90 's, the number of pheasants chicks was between 250 and 320 thousand, all were 6-8 weeks old.

This is also the period with the highest number of bagged game in the history of Vojvodina, and also in the history of hunting tourism in Serbia. The number of bagged game was about 25 - 32 thousand pheasants.

The positive side of increased number of pheasants chicks is not only the way of securing more game for the domestic hunters, but also for the foreign hunters. This is also the way to increase the number of mother flock.

Since the year 1991, for known reasons (the break up of Yugoslavia, wars in the near by countries, and other) the number of hunters drastically dropped, and hunting tourism almost completely disappeared.
\end{abstract}

Key words: Hunting tourism, pheasant population, Vojvodina region
Department of Geography, Tourism and Hotel Management, Faculty of Sciences, University of Novi Sad, Trg Dositeja Obradovića 3, 21000 Novi Sad, Serbia

\section{Introduction}

The pheasant has been present in Europe for at least 2500 years, and yet had no important role as a hunting game before $14^{\text {th }}$ and $15^{\text {th }}$ century, and only in some European countries. In $17^{\text {th }}$ century it became more widely spread, and in the last century it had been widely introduced at more areas in Europe. In spite of mass introduction and sheltering of this ecologically very plastic species in different biotopes, autochthonous small game species as brown hare and quail were main game species in many European countries, regarding both number and catch.

Only in 1960's, when in Central, Eastern and Southern Europe number of quails began to decrease, mass production of pheasant youngsters begins, as well as their introduction into hunting grounds. Since then in most of European countries the pheasant becomes a main hunting game. This period is still lasting and it will be noted in hunting and ecological literature as largest introduction of a game species in whole history of human society. Tens of millions of pheasants of different ages were released in different biotopes, causing immense consequences in present biocoenoses.

In areas of ex-Yugoslavia, as well as in Serbia, important introduction of pheasant begun only in the last century, but only in limited areas of royal and noblemen hunting grounds. Pheasant sheltering in our parts of Europe did not match other middleEuropean countries, which can be seen by data on modest catch: until World War II it did not exceed 45.000 birds per year.

\section{The Problem, Object and Aim of Investigation}

The hunting tourism generally means providing services to interested domestic and foreign tourist hunters, organized visits to hunting grounds due to shooting of big and small game, or only to watching or taking pictures (photo-safari) of the game, as well as paying certain compensation as listed in price list of every hunting ground.

On the basis of data collected regarding pheasant catch in hunting tourism for last
20 or more years, hunting tourism had its ups and downs. Increase of hunting tourism in Vojvodina was noted between 1961 and 1970, then an expansion from 1971 to 1990 and afterwards the hunting tourism was almost destroyed due to well-known reasons.

The aim of these investigations is to ass es and to analyze available data regarding total pheasant hunting tourism in Vojvodina, and to draw conclusions and recommendations for work in following period.

It is important to know the state of hunting tourism in previous period, since this is a good basis and a road-sign so the all mistakes ever made are not to be repeated in the next period.

\section{Methodology of Investigation}

The material for this paper had been collected from hunting evidence of Hunters Association of Vojvodina, from Long-Term Development Program for Hunting in Vojvodina (1984 and 2000-2010) and from Proceedings of papers regarding hunting during previous period.

Data about hunting evidence for hunting grounds in Vojvodina are shown in $\mathrm{Ta}$ -

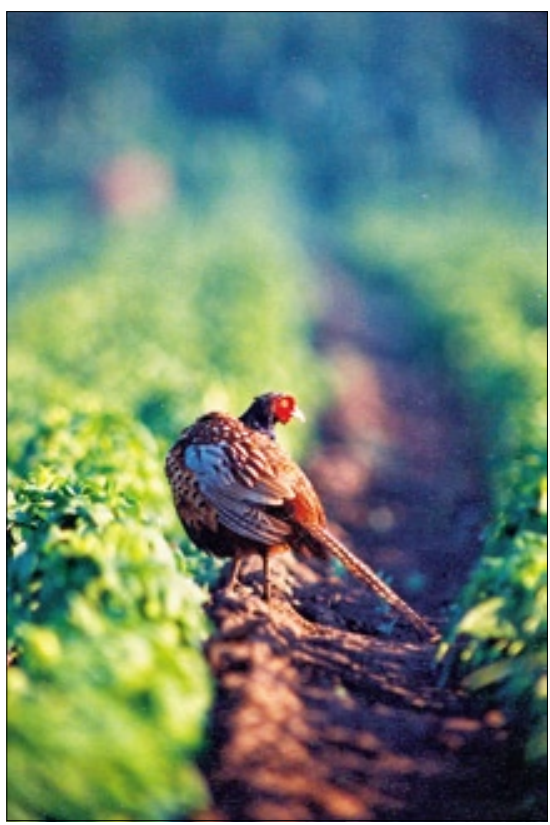

Figure 2 Pheasant in the crop fields of the Vojvodina region 
ble 1 and Figure 1 . The table presents data about pheasant from 1973 to 2000: spring number, total number of young pheasants introduced and total catch of pheasant in hunting tourism between 1979 and 2000 . The pheasant, as a bird game, has given biggest contribution to development of hunting tourism. This is especially important because it is alochthonous game species that is produced artificially and which is introduced into our hunting grounds in order to protect autochthonous species as the hare and the quail (Figure 2, 3, 4, 5, 6).

\section{Previous Investigations}

On the basis of previous data by Hanuš and Fišer (1975) if all principles of right technique and release are respected, in optimal conditions and with good care about pheasants, the catch of $50 \%$ released males could be achieved. This is not a maximum result, since there are hunting grounds where catch exceeds $60 \%$, but in average this is about 35\% from chicks released. The losses in released young pheasants are hard to perceive. Dead individuals are registered only in close proximity to the shelter, and even this is only partial. According to the same authors, release losses before hunting season are about $30 \%$ from number of pheasants released, and about $20 \%$ is due to environment change (stress, eating disorders, etc) and $10 \%$ losses are by predators.

The same authors say that it used to be normal to shoot $20-30 \%$ females from pheasants released. Nevertheless, if the number of pheasants has significantly decreased, it is necessary to reduce catch of females and to fill out the basic flock, which means to concentrate female catch in the hunting ground core (the circle of supposed dispersion of game released) and to spare females in peripheral parts of hunting grounds, which are inhabited by pheasants from local population.

According to investigation in Ireland in permanently controlled experiment with sheltered 5-weeks-old pheasant chicks, about $69 \%$ chicks die or disappear before they reach 12 weeks. Losses are caused by fox $(45 \%)$, pesticides (13\%), traffic (12\%) and other (4\%), while for $26 \%$ of losses the cause was not established.

From the practice of pheasant introduction in Vojvodina it is known that percent of pheasants caught in comparison to released was very differing, which can be explained by different habitat conditions, but also by sheltering malpractice. Therefore in hunting grounds of Hunters Society Mali Radinci catch was $52 \%$ of chicks released (1986), and in hunting grounds of Hunters Society Novi Sad it was under $10 \%$.

Investigations by Ristić (2005a) on the pheasants released in hunting grounds in Vojvodina, from 5.397.946 individuals released during 1973-2000 period, catch per-
Table 1 Spring number, number of pheasant chicks introduced, catch and percent of catch in comparison to released pheasants for 1973-2000 period and catch in hunting tourism in Vojvodina

\begin{tabular}{|c|c|c|c|c|c|}
\hline Year & $\begin{array}{c}\text { Spring } \\
\text { number, } \mathrm{Ne}_{1}\end{array}$ & $\begin{array}{c}\text { Pheasants } \\
\text { introduced, } \mathrm{N} \text { juv }\end{array}$ & $\begin{array}{c}\text { Catch, } \\
\Delta N\end{array}$ & $\begin{array}{c}\% \Delta \mathrm{N} \text { from } \\
\mathrm{N} \text { juv }\end{array}$ & $\begin{array}{c}\text { Total catch in } \\
\text { hunting tourism }\end{array}$ \\
\hline 1973 & 295,172 & 97,240 & 139,709 & 143.6 & \\
\hline 1974 & 315,826 & 124,263 & 126,973 & 102.2 & \\
\hline 1975 & 262,275 & 151,287 & 132,887 & 87.8 & \\
\hline 1976 & 277,839 & 157,494 & 113,904 & 72.3 & \\
\hline 1977 & 241,984 & 180,287 & 129,403 & 71.8 & \\
\hline 1978 & 244,845 & 180,813 & 127,634 & 70.6 & \\
\hline 1979 & 244,586 & 200,406 & 145,776 & 72.7 & 29,898 \\
\hline 1980 & 258,075 & 218,372 & 141,845 & 64.9 & 26,861 \\
\hline 1981 & 260,240 & 243,654 & 156,945 & 64.4 & 31,484 \\
\hline 1982 & 283,270 & 270,304 & 167,770 & 62.1 & 31,122 \\
\hline 1983 & 307,359 & 283,779 & 194,927 & 68.7 & 31,536 \\
\hline 1984 & 311,394 & 301,031 & 194,820 & 64.7 & 25,678 \\
\hline 1985 & 284,012 & 319,865 & 178,685 & 55.8 & 30,882 \\
\hline 1986 & 294,561 & 329,411 & 172,095 & 52.2 & 24,414 \\
\hline 1987 & 258,860 & 284,424 & 145,486 & 51.1 & 23,088 \\
\hline 1988 & 214,105 & 319,792 & 163,941 & 51.3 & 29,857 \\
\hline 1989 & 235,502 & 311,139 & 151,078 & 48.6 & 25,843 \\
\hline 1990 & 208,101 & 300,035 & 143,612 & 47.9 & 26,419 \\
\hline 1991 & 207,189 & 230,844 & 62,640 & 27.1 & 581 \\
\hline 1992 & 173,946 & 118,448 & 62,461 & 52.7 & 643 \\
\hline 1993 & 141,646 & 39,357 & 72,910 & 185.3 & 324 \\
\hline 1994 & 180,779 & 97,869 & 70,685 & 72.2 & 1,414 \\
\hline 1995 & 214,136 & 102,226 & 62,000 & 60.6 & 791 \\
\hline 1996 & 179,417 & 113,633 & 41,613 & 36.6 & 1,733 \\
\hline 1997 & 169,864 & 113,882 & 50,380 & 44.2 & 2,376 \\
\hline 1998 & 170,957 & 108,619 & 43,898 & 40.4 & 1,092 \\
\hline 1999 & 161,938 & 106,164 & 42,495 & 40.0 & 98 \\
\hline 2000 & 147,954 & 93,128 & 31,431 & 33.8 & 99 \\
\hline
\end{tabular}

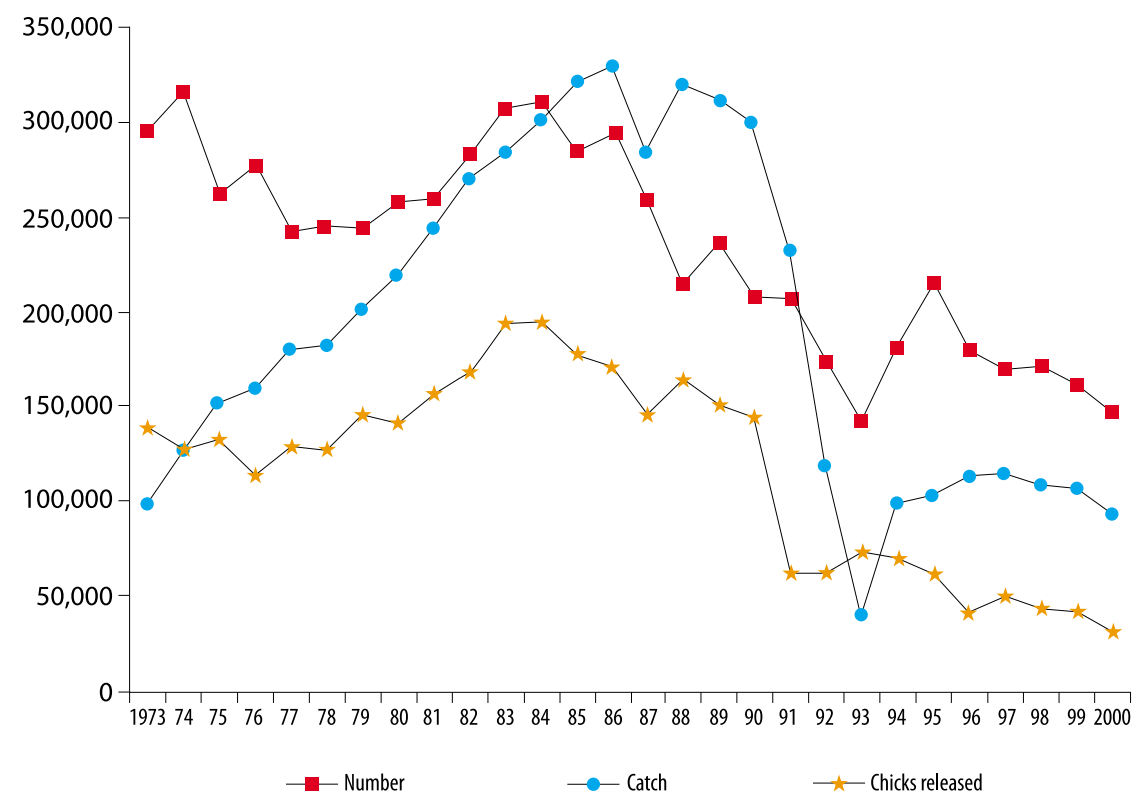

Figure 1 Population number, catch and chicks introduction in hunting grounds of the Vojvodina region in the period from 1973 to 2000. 


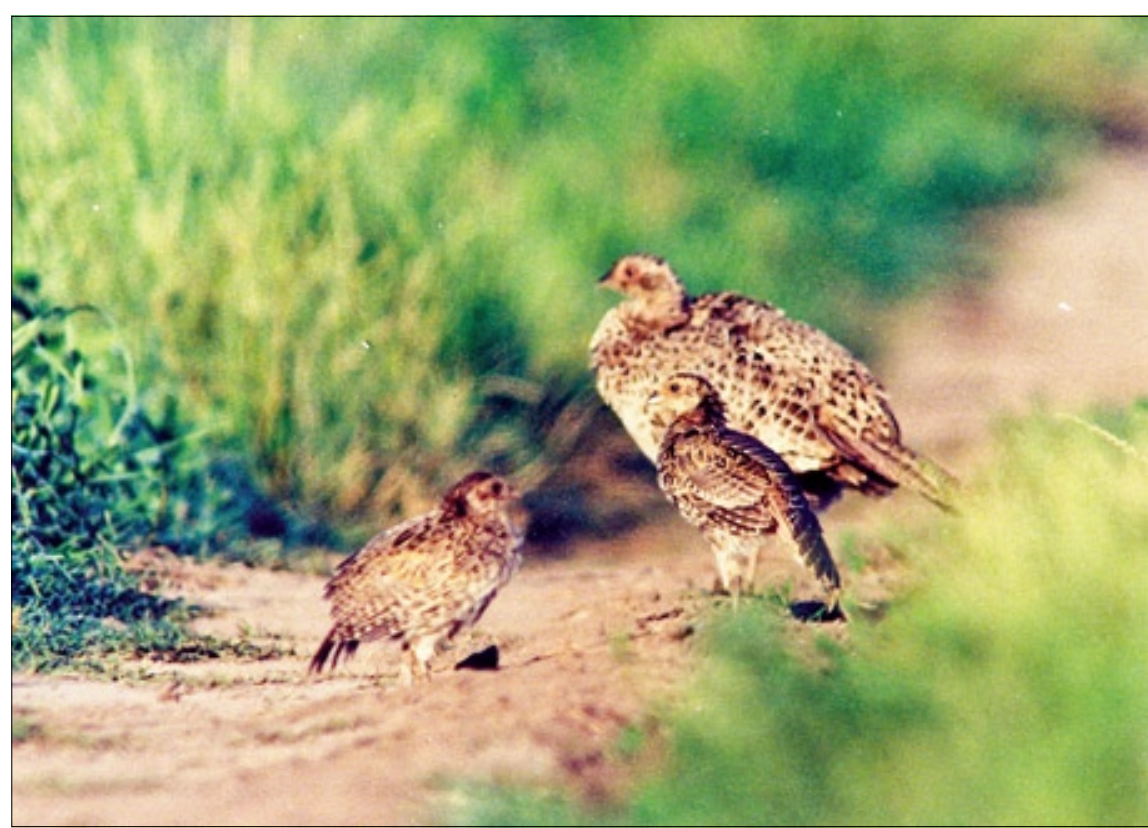

Figure 3 Pheasant mother with the chicks

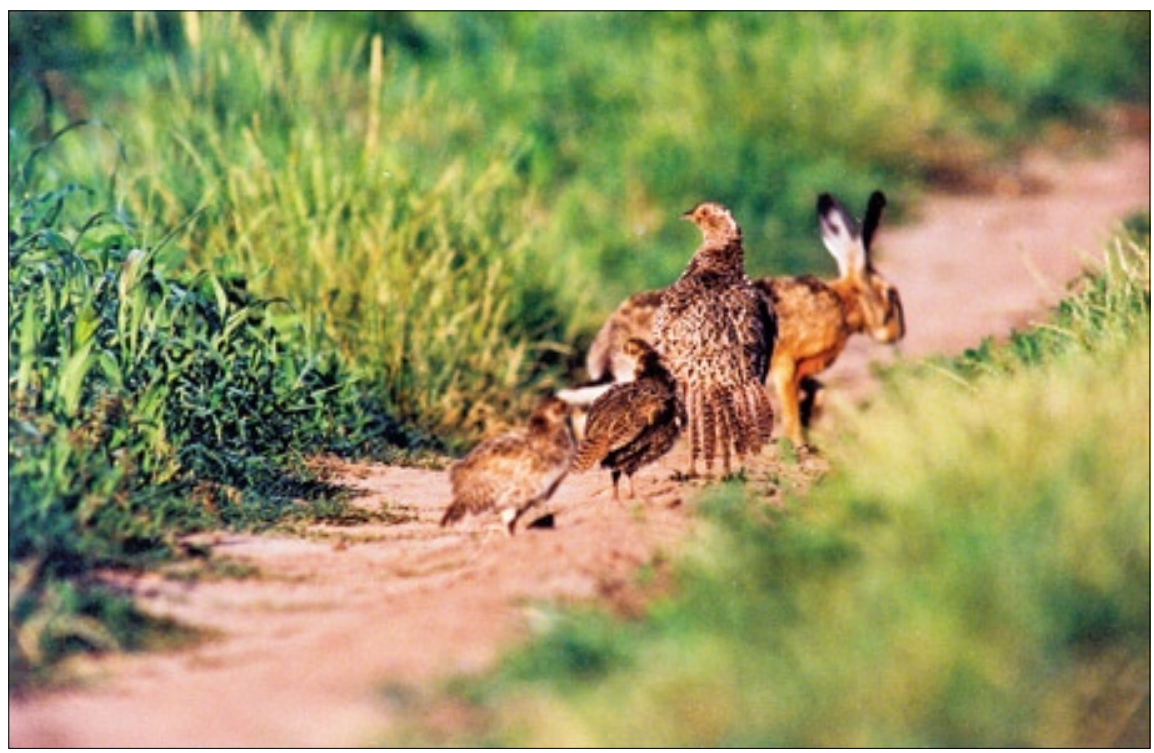

Figure 4 Pheasant family near a rabbit in the natural habitat

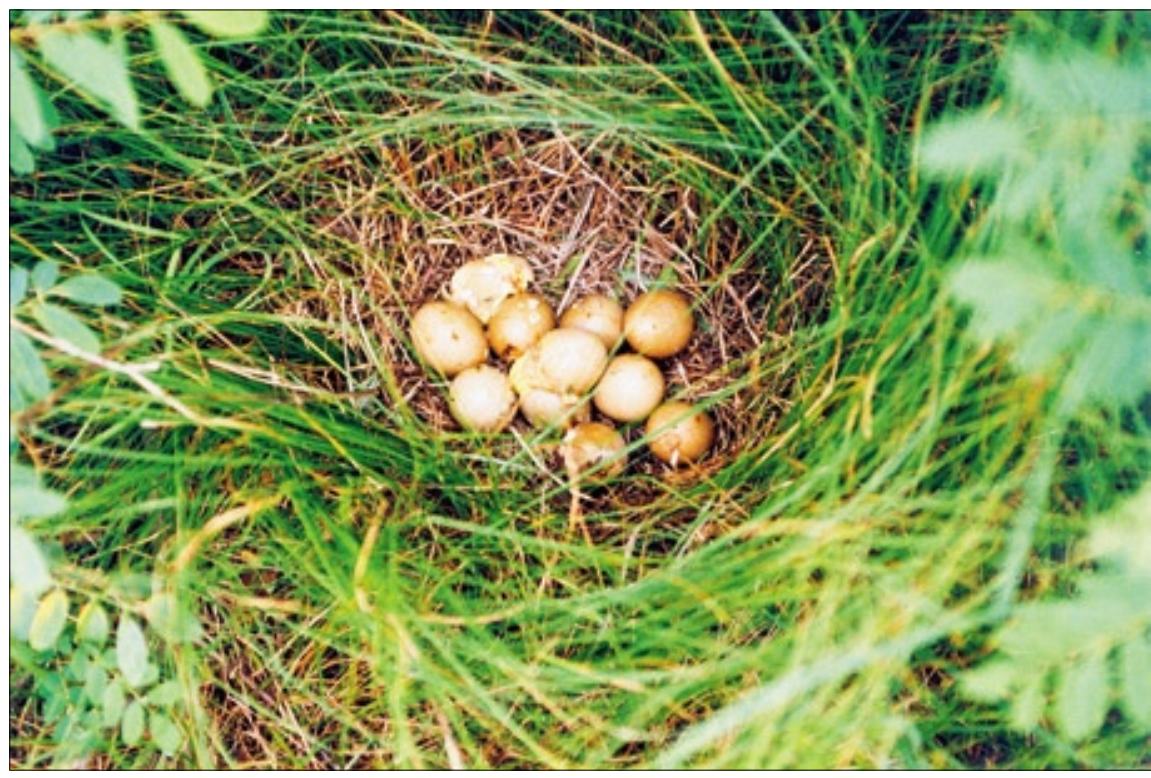

Figure 6 Pheasant nest in natural habitat cent was ranging between $28.77 \%$ in 1973 and $10.54 \%$ in 2000 , or in average $22.02 \%$ for the whole period.

On the basis of investigations by Ristic et al. (1995) it was established that in forest hunting grounds, where 6-weeks-old pheasant chicks were sheltered and then fed and controlled until the hunting season, catch percent was between $38.10 \%$ and $54.69 \%$ or in average $47.52 \%$. In open hunting grounds, where 6-weeks-old pheasant chicks were also released in shelters and after another six weeks introduced into hunting grounds, catch percent was between 7.40 and 39.30 or in average $22.53 \%$. These data were collected in seven hunters' societies during threeyear period (1989, 1992, and 1993). Total of 11,063 pheasants was released, from which 6,401 or $57.86 \%$ were marked. Total catch was 4,900 pheasants or $44.29 \%$ of pheasants introduced, and from these 1,442 were marked, which is $22,53 \%$.

Similar results are presented in investigation of Zeremski et al. (1999) for one forest hunting ground and for three hunters' societies. Total of 10,000 chicks was released in forest hunting ground, and 5,980 or $59.80 \%$ were caught. Into open hunting grounds of hunters' societies 4,224 pheasant chicks were released after sheltering, and 1,720 or $40.72 \%$ were marked. From these, total of 1,575 pheasants was caught, or $37,29 \%$ from released number. Total of 367 marked pheasants was caught (21.34\%)

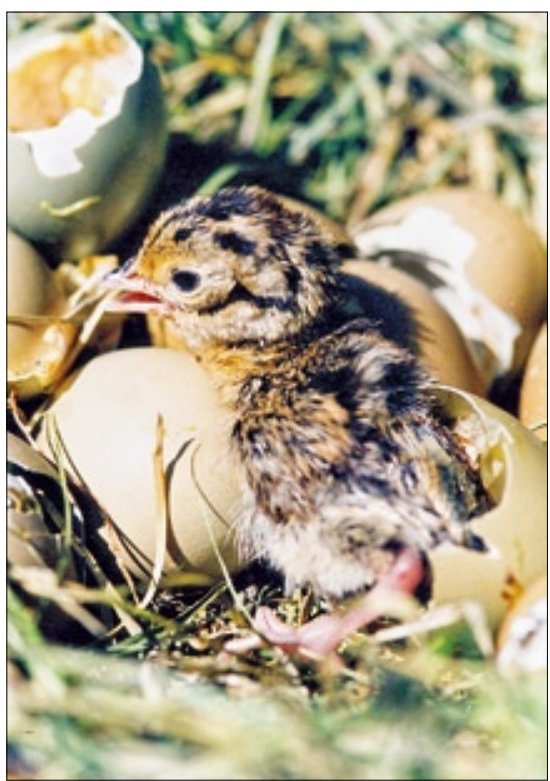

Figure 5 Hatching of pheasant chicks in natural habitat

while in comparison to total catch this was about $23.30 \%$.

On the basis of investigations by Hanuš and Fišer (1975) in different types of hunting grounds in Czechoslovakia during three-years period about 72,000 released pheasants were marked. Investigation has been carried out in 11 pheasant forest hunting grounds with different breeding systems. Data were recorded regarding body 
weight of pheasants from artificial breeding in comparison to those from natural breeding, dispersion of pheasants from release point depending on different environment conditions, percent of artificially bred pheasants which live to next hunting season, influence of environment to catch of these pheasants etc. Pheasants were marked by cutting off the fourth finger.

According to results of investigations, catch of released pheasants ranged from $22.2 \%$ to $55.6 \%$. Most of artificially bred pheasants are being caught in the same year. Catch of two-years-old pheasants in this investigation was only $2.7 \%$ in average, so it can not be counted on significant survival of released pheasants until the second hunting season. Percent of pheasants caught in the third hunting season is quite insignificant.

Investigation of artificially bred pheasants dispersion from release point was carried out on the basis of data concerning 9,325 marked pheasants being caught. According to data obtained, $94 \%$ of pheasants are being caught up to $1000 \mathrm{~m}$ from the releasing point, and only $6 \%$ at the larger distances. Average dispersion distance in investigated hunting grounds was only $427 \mathrm{~m}$.

By weight measurements of 2,242 pheasants caught in 11 hunting grounds it was established that average weights of released pheasants were not different from those of free-bred pheasants. Maximum body weight in artificially bred pheasants was 1.94 $\mathrm{kg}$ in males and $1,46 \mathrm{~kg}$ in females, while in free-bred pheasants weight was $1.64 \mathrm{~kg}$ and $1.42 \mathrm{~kg}$, respectively. Differences in average weight between certain hunting grounds are obviously depending on food quantity and quality. In pheasants caught in November, average weight was quite bigger than in those caught in October.

In order to decrease losses in released pheasants and to increase catch percent, according to investigations of Hanuš and Fišer (1975), it is necessary:

- to provide adequate protection from predators at the releasing points;

- to pay maximal care to preparing environment in releasing areas;

- to provide absolute peace in time of releasing and to release pheasants in small groups - no more than 100 pheasants per day; in this way, stress as a consequence of sudden environment change will be reduced;

- to release pheasants in nice and stable weather only;

- to provide food and water to pheasants in a shelter as long as they are returning there, and later only in areas outside the shelter, etc.

\section{Releasing of Pheasants}

Problems of pheasant releasing and its influence on environment must be considered together as a complex matter. Prob- lems are numerous and different, from ethical and esthetical, economical and sociological, and biological and ecological ones. It is necessary to synthesize investigations of every group of problems in order to provide an overall impression.

Releasing of pheasants could be divided into five categories: 1) releasing in order to acclimatize in favorable habitats with no pheasants whatsoever; 2) releasing in order to provide increased flock density; 3) releasing in order to change (improve) the genetic pool; 4) releasing in order to provide dense populations before hunting season and 5) releasing in order to hunt.

First three categories are - as a rule one-time releases and may be done again after some time.

Releasing pheasants in order to form a population in favorable habitats with good conditions was especially often until the end of 1960's. In those times pheasant eggs

was in fashion during sixties. Today is well known that a pheasant - common, game or European game pheasant - is a mix between common "bohemian" pheasant (Ph. c. colchicus L), ring-necked pheasant - Chinese pheasant (Ph. c. torquatus Gmelin), Mongolian pheasant (Ph. c. mongolicus Brandt), and many other subspecies (Ristić, 2005a).

Releasing the adult pheasants from breeding units directly in front of the hunters' guns is certainly disqualified not only by hunting ethics, but by any ethics whatsoever. Nevertheless, this way of releasing does the least ecological damage, and certainly is the most profitable one. These pheasants simply have no time to influence negatively present wild populations (if there are any) or other members of biocoenoses, since they are promptly eliminated. Using term "killing" instead of "hunting" is more appropriate since this

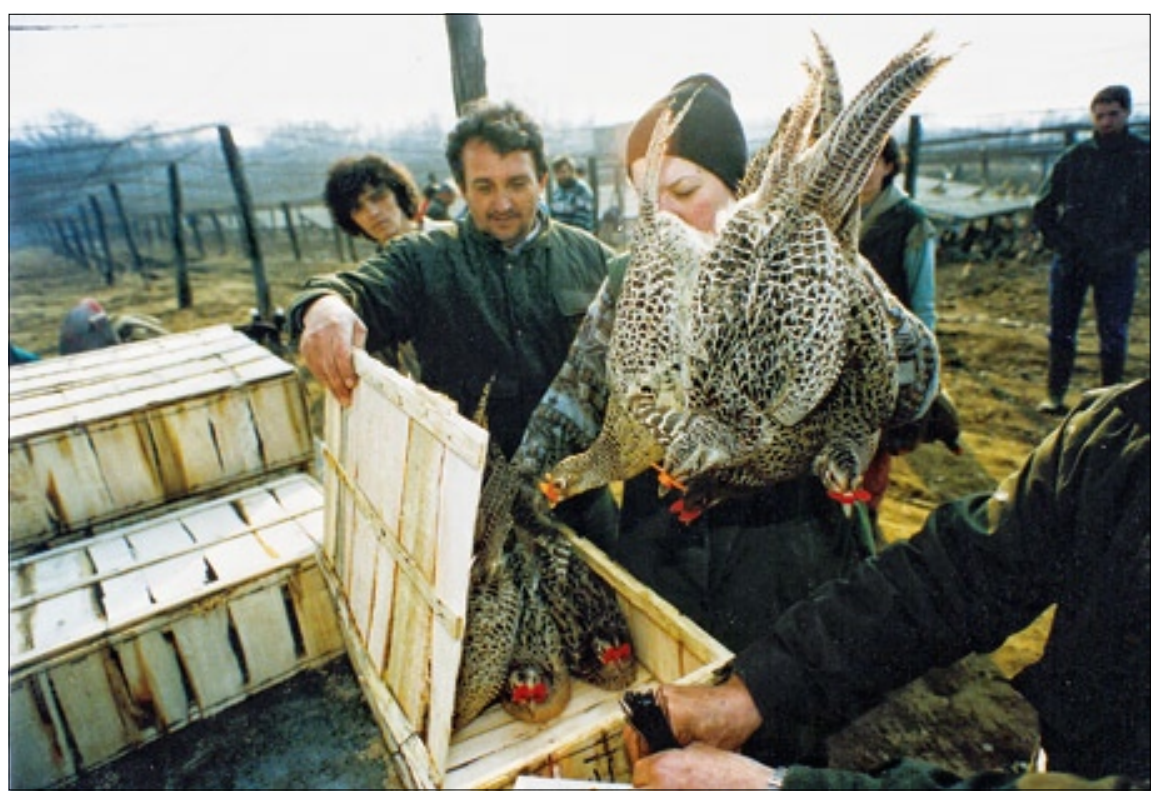

Figure 7 Preparation of the spring flock

were mostly hatched using domestic hens (so-called "semi-wild" way). Due to nature of breeding, they were released in smaller groups (300-750 pheasant chicks with 2050 hens). In this way, in best habitats micropopulations were obtained able to survive and to naturally breed and disperse.

Releasing in order to increase population density in basic flocks and to improve genetic pool of certain populations has been done in much smaller scope, and with adult individuals before reproductive period. Time of this type of release is mostly the same as the time for releasing in order to form a population and is a kind of "second chance" if that was not successful, mostly due to wrong choice of a habitat. In first years of population forming, no attention was paid to basic ecological factors and to interactions of biocoenoses factors, which was later analyzed in detail. It is hard to judge "blood refreshments" which activity is much different from hunting, but also from skeet shooting.

Regarding releasing pheasants in order to increase seasonal micropopulation before hunting season, it is considered to have huge and yet not estimated damage to relatively well preserved biocoenoses in whole Europe, especially in its eastern parts. We will not consider damages by introducing pathogenic agents, since there are other competent specialists in this area. Much bigger damages are due to biocoenoses disturbances, where pheasants were introduced en gross with no preliminary work whatsoever.

\section{Discussion and Conclusions}

Intensity (and a way) of introduction, i.e. release of individuals from breeding posts into a population certainly influences its dynamics. There are different opinions regarding this influence in pheasants popu- 


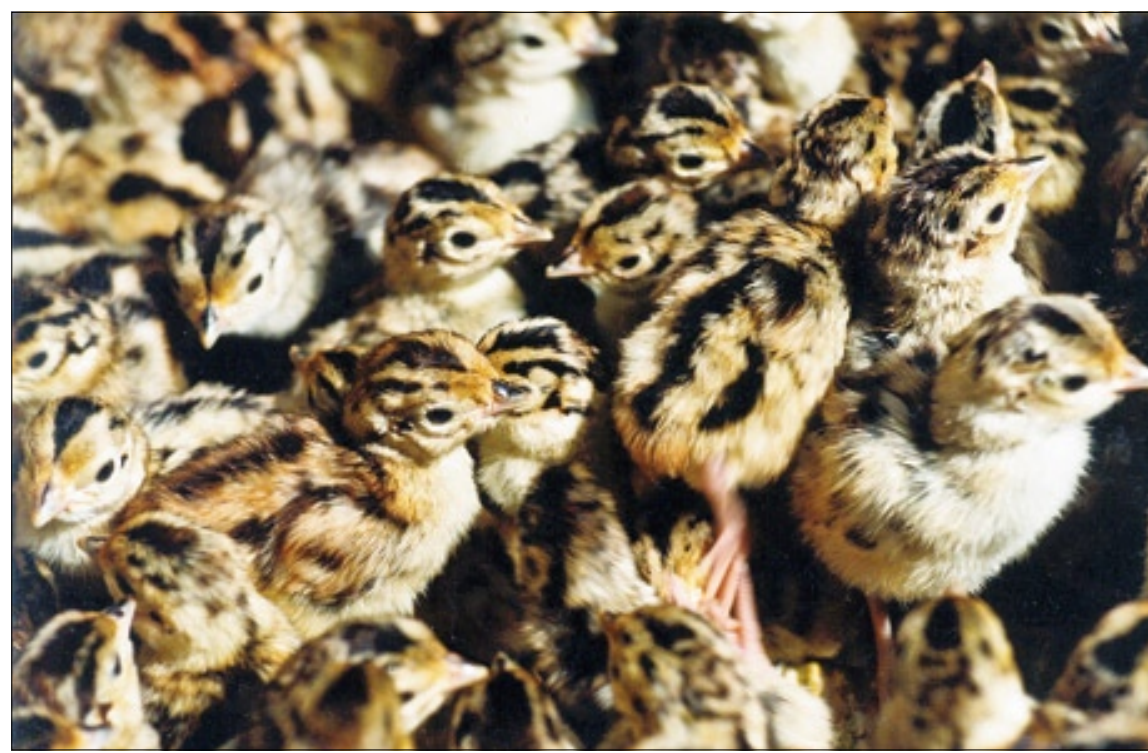

Figure 8 Pheasant chicks in pheasant farm

lation. Previous investigations of survival level of young individuals introduced, using loss level or a catch rate (Pekić, 1960; Hanuš and Fišer., 1967; Ristić et al.,1995; Zeremski et al. 1999; Ristić, 2005a, 2005b) had different results.

This paper investigates megapopulation dynamics in Vojvodina during 1973-2000 period (Table 1 and Figure 1) using data from official evidence of Hunters Association of Vojvodina.

From number dynamics and its relationship to introducing and usage level it may be found that from mid-seventies number of pheasants caught is generally smaller than a number of chicks released ( $\mathrm{N}$ juv), so the catch is relatively decreasing. By increasing introduction intensity, a disproportion between pheasants introduced and caught is being increased until 1993 when this relationship was in favor of catch, but the catch was not large. Catch is in highly positive correlation to spring number of megapopulation. Spring number and catch are very sensitive to drastic decrease of introduction.

Introduction of artificially bred pheasants into hunting grounds of Vojvodina, mostly by 5,8 , or 12 weeks old chicks, in order to obtain numerous seasonal populations before the hunting season, did not give results as expected.

Disproportion between the number of pheasants introduced (Figure 7) and the catch is increasing with increased introduction. Causes of this disproportion should be find mostly in nonselective choice of habitats for introduction, in a way of sheltering young pheasants in hunting grounds, and in total changes in biocoenoses, and not in genetic degradation of a megapopulation. The megapopulation could not be judged only by some proprieties in its dynamics. The data regarding genetic diversity and biotopes are also necessary. Intensive releasing of young pheasants (5-8 weeks old) into hunting grounds during summer months (July, August) in or-

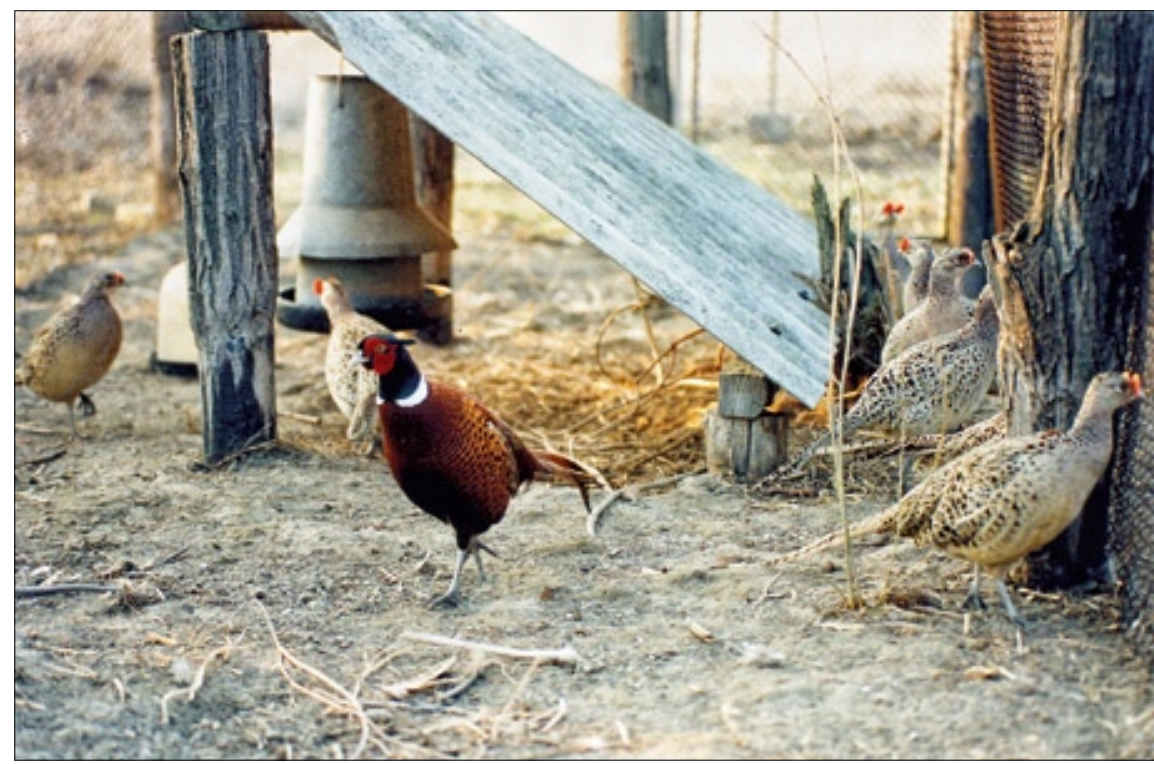

Figure 9 Pheasants at the pheasant farm (voliera) der to obtain numerous seasonal populations before the hunting season must be re-considered: not only because of a way of sheltering young pheasants in hunting grounds, but mostly because of such introduction influences present pheasant population, as well as populations or other (autochthonous) small game (hare and quail) and finally the biocoenosis as a whole (Ristić, 2005a).

Maybe a pause in intensive pheasant release to free habitats, caused by lack of resources from hunting tourism, is a fine opportunity to investigate these relationships, having in mind economical aspects as a result of hunting. Our hunting research should see into this and propose optimal solutions for both hunting organizations and for pheasant breeders.

On the basis of investigations by Ristić (2005a), from total catch of seven

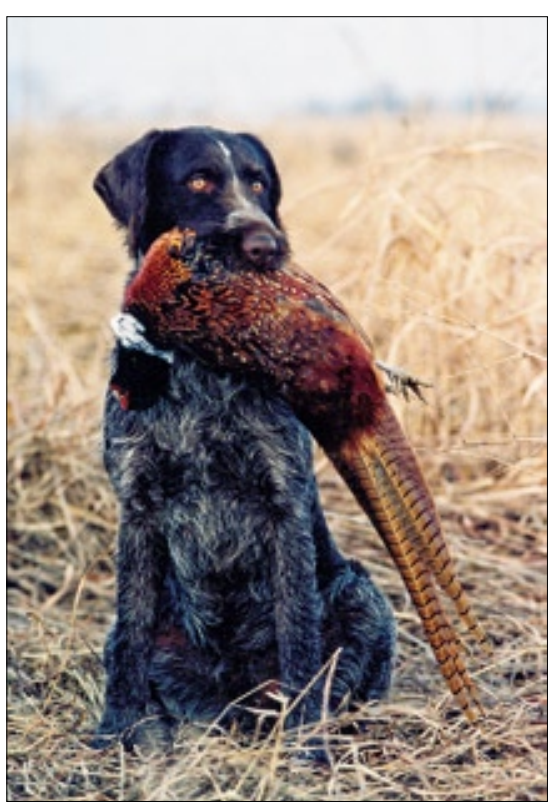

Figure 10 The dog bringing the shot pheasant

bird game species in Vojvodina (pheasant, quail, turtledove, collared dove, wild goose, wild duck and partridge) during 1979-2000 period when total of 5,194,436 these birds were caught, catch of pheasant was $2,497,493$ or over $48 \%$. Expressed in euros, total income in foreign currency in hunting tourism for seven bird game species was 10,582,180 euros, and for pheasant $4,584,063$ euros, or over $43 \%$.

That is why we think that the pheasant is still a bird game which had, and still has, its place in hunting tourism in Vojvodina and in wider area.

In order to obtain significant results, we recommend to introduce much more pheasant chicks from artificial breeding (Figure 8, 9) in hunting grounds during last ten years in Vojvodina it was 40-115 thousand by year, and before 1991 even over 300 thousand per year (Table 1), to use classic methods of sheltering 6-8 weeks old pheas- 
ants chicks, to work on developing annual and permanent groves - which will improve habitat conditions for pheasant and other game species - and to hunt it during a whole hunting season (Figure 10, 11).

\section{References}

Hanuš V., Fišer Z. 1975. "Bažant” - Fazan (gajenje i lov), Nolit - Beograd, 1-196.

Godišnji izveštaj o naučno istraživačkom radu LSZ, Beograd, oktobar, 1999. page. 28-29.

Pekić B. 1960. Koliko fazana ostane u životu. Lovačka revija 5, 70-71.

Ristić Z. 2005a. Fazan, monografija. AMB "Grafika", Novi Sad, 1-592.

Ristić Z. 2005b. Procenat odstrela od unetih fazančića u lovišta. Turizam 9, 164167.

Ristić Z. Đaković D., Novkov M., Zeremski M. 1995. Stepen preživljavanja fazančića unetih u lovište -prvo saopštenje o rezultatima istraživanja u Vojvodini. Zbornik radova Lovačkog saveza Jugoslavije sa savetovanja u Novom Sadu, 9398.

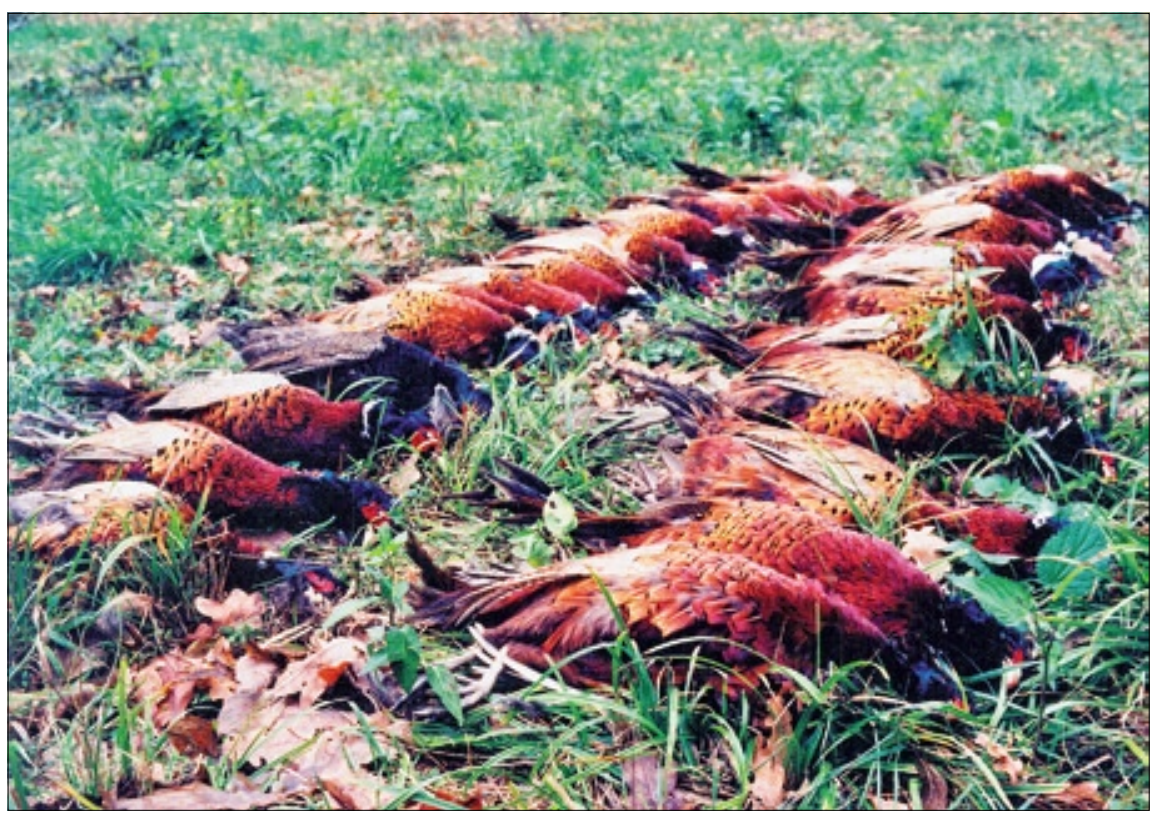

Figure 11 Successful pheasant hunt

Zeremski M., Novkov M., Beuković M., Ristić Z., 200o. Stepen preživljavanja fazančića puštenih u lovište iz naučnoistraživačkog rada LSS i LSV, Lovačke novine XXXIX, 12, 9. 